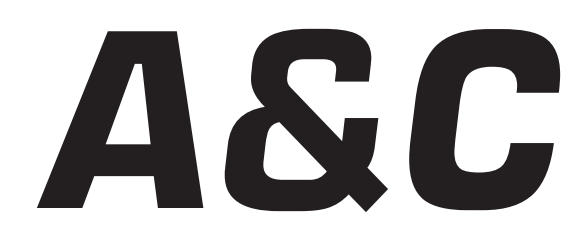

Revista de Direito Administrativo \& Constitucional

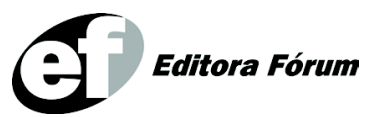

ISSN 1516-3210 


\section{A\&C REVISTA DE DIREITO ADMINISTRATIVO E CONSTITUCIONAL}

IPDA

Instituto Paranaense

de Direito Administrativo

Direção Geral

Romeu Felipe Bacellar Filho

Direção Editorial

Paulo Roberto Ferreira Motta

Direção Executiva

Emerson Gabardo

Conselho de Redação

Edgar Chiuratto Guimarães

Adriana da Costa Ricardo Schier

Célio Heitor Guimarães

\section{Conselho Editorial}

Adilson Abreu Dallari

Alice Gonzáles Borges

Carlos Ari Sundfeld

Carlos Ayres Britto

Carlos Delpiazzo

Cármen Lúcia Antunes Rocha

Celso Antônio Bandeira de Mello

Clèmerson Merlin Clève

Clóvis Beznos

Enrique Silva Cimma

Eros Roberto Grau

Fabrício Motta

Guilhermo Andrés Muñoz (in memoriam)

Jaime Rodríguez-Arana Muñoz

Jorge Luís Salomoni

José Carlos Abraão
José Eduardo Martins Cardoso
José Luís Said
José Mario Serrate Paz
Juan Pablo Cajarville Peruffo
Juarez Freitas
Julio Rodolfo Comadira
Luís Enrique Chase Plate
Lúcia Valle Figueiredo
Manoel de Oliveira Franco Sobrinho
(in memoriam)
Marçal Justen Filho
Marcelo Figueiredo
Márcio Cammarosano
Maria Cristina Cesar de Oliveira

Nelson Figueiredo

Odilon Borges Junior

Pascual Caiella

Paulo Eduardo Garrido Modesto

Paulo Henrique Blasi

Paulo Neves de Carvalho (in memoriam)

Paulo Ricardo Schier

Pedro Paulo de Almeida Dutra

Regina Maria Macedo Nery Ferrari

Rogério Gesta Leal

Rolando Pantoja Bauzá

Sérgio Ferraz

Valmir Pontes Filho

Yara Stropa

Weida Zancaner

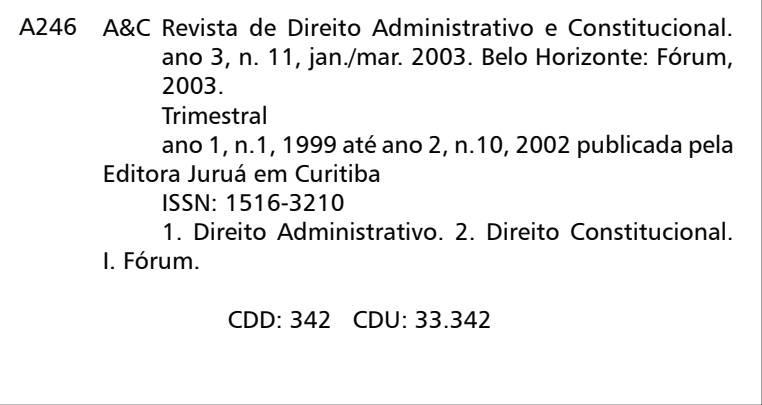

(C) Editora Fórum Ltda. 2007

Todos os direitos reservados. É proibida a reprodução total ou parcial, de qualquer forma ou por qualquer meio eletrônico ou mecânico, inclusive através de processos xerográficos, de fotocópias ou de gravação, sem permissão por escrito do possuidor dos direitos de cópias (Lei nº 9.610, de 19.02.1998).

Editora Fórum Ltda

Av. Afonso Pena, $2770-15 \% 16^{\circ}$ andar - Funcionários

CEP 30130-007 - Belo Horizonte/MG - Brasil

Tel.: 08007043737

Internet: www.editoraforum.com.br

e-mail: editoraforum@editoraforum.com.br
Editor responsável: Luís Cláudio Rodrigues Ferreira Projeto gráfico e diagramação: Luis Alberto Pimenta Revisora: Olga M. A. Sousa

Pesquisa jurídica: Fátima Ribeiro - OAB/MG 74868

Bibliotecária: Leila Aparecida Anastácio

CRB 2809/MG 6ª região

Os conceitos e opiniões expressas nos trabalhos assinados são de responsabilidade exclusiva de seus autores.

Impressa no Brasil / Printed in Brazil

Distribuída em todo Território Nacional 


\title{
Limites à imposição de sanções administrativas - Multas pecuniárias tributárias
}

\author{
Frederico Valdez Pereira
}

Advogado.

Palavras-chave: Direito Administrativo. Direito Administrativo - novos paradigmas. Infrações e sanções penais. Infrações e sanções administrativas. Direitos fundamentais.

Sumário: 1 Introdução - 2 Sanções penais e sanções administrativas - 3 Novos paradigmas do Direito Administrativo - 4 A incidência dos princípios do não-confisco e da proporcionalidade sobre as multas tributárias pecuniárias - 4.a Princípio do não-confisco - 4.b Princípio da proporcionalidade - Conclusão - Referências

\section{Introdução}

O objeto do presente trabalho é o desenvolvimento de um estudo sobre as influências e os reflexos que as transformações do Direito Administrativo vêm trazendo sobre o tema de infrações e penalidades tributárioadministrativas, mormente no que tange aos pressupostos e limites na escolha da sanção aplicável no caso concreto.

Desde já se destaca que os ramos tributário e administrativo são didaticamente estudados de forma separada, com princípios e noções próprios, ${ }^{1}$ que os especializam em relação aos demais ramos da ciência jurídica. ${ }^{2}$ Nesse estudo, vão se preservar essas notas que as distinguem. Não se cometerá a heresia de confundir os aspectos especializadores desses ramos do Direito, tampouco fazer uma análise conjunta e confusa de

\footnotetext{
Não se pretende neste trabalho aprofundar a questão da "antiga polêmica mantida entre autores que rejeitavam a revisão de conceitos tradicionais do direito privado e os que defendiam, apoiados justamente na alegada autonomia dogmática do direito tributário. Estes últimos enfrentaram, ainda, a resistência dos administrativistas, que viam no direito tributário (ou no direito financeiro) mera província do direito administrativo, disciplinador de todas as relações entre o Estado e os administrados, inclusive, pois, as relações atinentes à obrigação tributária" (AMARO. Direito tributário brasileiro., p. 7).

2 "É necessário, nesse ponto, recorrer aos melhores autores, para não recair e permanecer no 'manicômio jurídico': "Pela simples razão de não poder existir regra jurídica independente da totalidade do sistema jurídico, a 'autonomia' (no sentido de independência relativa) de qualquer ramo do direito positivo é sempre e unicamente didática para, investigando-se os efeitos jurídicos resultantes da incidência de determinado número de regras jurídicas, descobrir a concatenação lógica que as reúne num grupo orgânico e que une este grupo à totalidade do sistema jurídico" (BECKER. Teoria geral do direito tributário, p. 29)
} 
ambas as searas jurídicas.

Até porque a doutrina de François Gény, que sustentou a tese de que o "particularismo" do direito fiscal se resumia a alguns aspectos técnicos, o que não implicava reconhecer-lhe autonomia, já foi suficientemente polemizada com Louis Trotabas, que defendia a posição autonomista do direito fiscal. Temos o entendimento de que, assim como na doutrina de François Gény, não há como se falar em autonomia deste ou daquele ramo do direito, querendo significar que ele teria vida própria e independente dos demais ramos da ciência jurídica, mas sim em um "particularismo exclusivamente legal", ou mesmo numa 'autonomia' didática'. Afora isso, o ordenamento jurídico é um todo unitário, e não se pode pretender entender ou destacar um ramo do direito, sem a sua concepção conjunta com o todo.

Nesse sentido, impõe-se sempre a referência a Norberto Bobbio:

Para que se possa falar de uma ordem, é necessário que os entes que a constituem não estejam somente em relacionamento com o todo, mas também num relacionamento de coerência entre si. Quando nos perguntamos se um ordenamento jurídico constitui um sistema, nos perguntamos se as normas que o compõem estão num relacionamento de coerência entre si e em que condições é possível essa relação. (Teoria do ordenamento jurídico. 10. ed. Tradução de Maria Celeste C. J. Santos. Brasília: Universidade de Brasília, 1999. p. 71)

Parte-se, é bem verdade, da noção de que inexiste uma distinção qualitativa nas infrações e respectivas conseqüências jurídicas - sanções — entre os ramos do direito. Obviamente não há como se negar que os pressupostos de aplicação das punições, bem como seus limites e resultados, a par de um balizamento Constitucional único, principalmente levando-se em consideração o catálogo dos Direitos Fundamentais do indivíduo, são distintos e com graus de atuação variáveis.

Pela própria razão de ser da previsão Constitucional desses Direitos de liberdade - limites ao Poder estatal de atuação na esfera jurídica privada e, por óbvio, de imposição e execução de sanções - e ainda não só pela limitação ao poder de definição de condutas proibidas, como também de restrições quantitativas e qualitativas sobre as penalidades aplicáveis abstratamente sobre os comportamentos lesivos é necessário reconhecer que há uma conotação geral e abstrata de infração e sanção na ordem jurídica unitária, na concepção vista acima.

No entanto, preservando-se as distinções e notas especializantes, 
não há como se negar que, no que tange à questão sancionatória, é possível a consideração conjunta tanto da fundamentação dessas punições como de suas origens, características e, principalmente, em relação àquilo que será o objeto central dessa valoração, os limites das sanções administrativas.

E desde já saliente-se que as sanções tributárias são, antes de qualquer coisa, sanções administrativas. Pode haver, e realmente há, uma distinção qualitativa importante entre as punições penais e as penalidades administrativas. Mas, afora isso, é possível, sem o risco de se cometer nenhuma grande impropriedade, abranger as demais sanções jurídicas que não de natureza penal como sanções administrativas. Englobandose, portanto, como pertencente a essa última classificação, as sanções tributárias.

Inexiste diferença estrutural entre a sanção penal e a sanção administrativa, nem entre essas e a sanção tributária.

As normas do ordenamento jurídico que prevêem as sanções, sejam penais sejam administrativas, são normas de conduta que disciplinam comportamentos sociais. São estruturadas em forma de imperativos hipotético-disjuntivos.

A norma de conduta prevê a hipótese, a disposição e a sanção. Verificando-se a ocorrência de determinado fato, previamente previsto na norma de conduta, deve ocorrer determinada conseqüencia jurídica também prevista na regra. A não ocorrência dessa conseqüência é que faz com que atue a sanção.

A sanção não deixa de ser uma conseqüência, porém destinada a um comportamento que desrespeitou a eficácia jurídica natural da norma de conduta. ${ }^{3}$

Furlan explica que:

As principais sanções previstas para o descumprimento da obrigação de pagar tributo têm o traço da prestação pecuniária, embora possam consubstanciar-se em outras formas, como a apreensão de bens, perda de mercadorias e restrição de direitos. São as sanções administrativas (grifo meu). Ocorre que o Estado-legislador pode optar em descrever determinadas condutas contrárias ao direito e a elas imputar uma conseqüência de natureza penal (restrição da liberdade),

\footnotetext{
"Noutras palavras, a não-sujeição (à eficácia jurídica que se irradiou após a incidência da primeira regra jurídica) é elemento constitutivo da composição da hipótese de incidência da segunda regra jurídica, de modo que esta segunda regra jurídica somente incidirá se ocorrer aquela não-sujeição" (BECKER. Teoria geral do direito tributário, p. 316).
} 
qualificando-as, assim, como crimes ou contravenções. São os crimes tributários. (Sanções penais tributárias. In: MACHADO, Hugo de Brito (Coord.). Sanções penais tributárias. São Paulo; Fortaleza: Dialética/ICET, 2005. p. 16-17)

Feitas essas considerações iniciais, já é possível se inferir a importância do tema e sua atualidade na aplicação do direito administrativo e tributário na atualidade. O tributo é cada vez mais o principal meio pelo qual o Estado pretende adquirir meios para amenizar a carência dos serviços públicos prestados, alguns de extrema relevância, pela indispensabilidade na manutenção do ser humano com dignidade, como é o caso da saúde e dos sistemas de previdência e assistência social.

Isso faz com que a carga tributária aumente de forma desmedida e influa de forma decisiva no desenvolvimento econômico e social do país, ou na falta desse. Freqüentemente está-se diante de contribuinte que não conseguem manter em dia o pagamento dessas exações, o que acarreta a moratória e, por conseqüência, a imposição das penalidades administrativo-tributárias.

Além disso, vêm se multiplicando e majorando as penas administrativas em função do descumprimento de normas de conduta e de regulação das liberdades públicas pelo exercício do Poder de Polícia, como o exemplo das multas de trânsito.

Tudo isso faz com que haja um excesso de penalidades pecuniárias na atualidade, todas elas cobertas pelos atributos da imperatividade, presunção de legalidade e auto-executoriedade, inerentes à atividade administrativa.

No entanto, cada vez mais se valorizam e se prestigiam os Direitos fundamentais do indivíduo e os limites do Estado na ingerência sobre esses Direitos Constitucionais, desenvolvendo-se doutrinariamente teorias e idéias sobre os núcleos indevassáveis dos direitos de primeira geração e da necessária razoabilidade das normas punitivas.

Tudo isso gerou desenvolvimento e grande aplicação na doutrina e jurisprudência, com relevância para adoção da teoria, pelo Tribunal Constitucional, do princípio da Proporcionalidade, que pretende fazer um balizamento científico das colisões entre direitos fundamentais, ou entre esses e as atividades inerentes ao Estado-administrador: que se verifica na oposição entre as penalidades administrativas e os direitos de propriedade e razoabilidade nas punições impostas ao particular.

O tema, assim, será investigado de acordo, principalmente, com 
a evolução da jurisprudência brasileira e as teorias por ela utilizadas para regular o poder estatal de aplicação de penalidades administrativas, dandose destaque para os princípios do não-confisco e da Proporcionalidade, e suas influências e conseqüências práticas sobre a dimensão e quantidade de sanção aplicada pela Administração Pública sobre a alegação de punir e reprimir condutas contrárias ao direito no âmbito apenas administrativo.

Este trabalho está dividido nas seguintes partes: de início, vão se apresentar as semelhanças e dissensões entre as penas administrativas e as sanções penais. Na seqüência do trabalho, serão analisados os novos paradigmas do Direito Administrativo, mediante um paralelo, tentando localizar suas influências e diferenças de conotações sobre o tema das multas administrativas.

Ao final, então, far-se-á a compatibilização teórica entre os princípios originados dos Direitos Fundamentais: Proporcionalidade e nãoconfisco, com os limites Constitucionais ao Poder Estatal de definir e aplicar as sanções administrativas.

\section{Sanções penais e sanções administrativas}

É sabido que quaisquer normas de conduta ensejam o descumprimento, voluntário ou não, por aquele que deveria observá-la. Isso se dá em todos os setores do direito, seja no campo privado, seja no campo do direito público, seja em normas genéricas de conduta, seja naquelas destinadas a regular o comportamento interpartes.

Assim, a possibilidade de um procedimento contrário ao direito é possível de forma ampla nos diversos setores do ordenamento jurídico. Na seara do direito privado, o dever genérico de sujeição ao direito de outrem pode ser violado, como o exemplo do esbulho da propriedade alheia, ou de forma mais grave, a subtração de coisa alheia móvel. O dever específico de assunção de determinada conduta também pode ser descumprido, como na hipótese de o mutuário negar-se a devolver o bem alheio, ou então deixar de adimplir parcelas do contrato de compra e venda ou de aluguel.

No campo do direito público também são verificados, constantemente no convívio social, comportamentos contrários àqueles impostos pela norma jurídica, como são exemplos as infrações de trânsito ou o descumprimento do pagamento de determinado imposto no prazo legal.

Daí retira-se a singela noção de infração: conduta omissiva ou 
comissiva contrária ao direito.

O Direito utiliza-se do termo "infração" para designar a violação de uma norma de conduta prevista no ordenamento jurídico ou em simples cláusula contratual resultante de um acordo de vontades, quer se trate de matéria de direito público, quer de direito privado.

Diante da violação da norma jurídica ou da inobservância da cláusula contratual, a ordem jurídica prevê a aplicação de um castigo, que pode variar da simples advertência à restrição ou diminuição de direitos — no mais das vezes, de ordem patrimonial, como é o caso das penalidades pecuniárias - podendo afetar, ainda, a liberdade pessoal do infrator e até a vida, o bem jurídico mais precioso.

Conforme referido na parte introdutória, a infração gera uma conseqüência jurídica que é a aplicação de remédios legais que buscam repor a situação pretendida pela ordem jurídica - execução coercitiva da obrigação descumprida; ou então reparar o dano causado ao direito alheio, através de obrigação indenizatória; ou ainda a possibilidade de punir o agente que cometeu o comportamento ilícito, aplicando-lhe um castigo expressa e previamente regulado pela ordem jurídica. Nessa última hipótese é que se terá a sanção, ou seja, a punição pelo fato da conduta ilícita.

Vê-se que não há, ontologicamente, uma diferença entre o ilícito civil, administrativo ou ilícito penal. Tanto que é inegável que um mesmo fato pode, dependendo de circunstâncias históricas ou geográficas, ser considerado por um determinado ordenamento jurídico lícito, ilícito civil ou administrativo e ilícito criminal. O que hoje é um crime, pode não ter sido assim considerado ontem, ou deixar de sê-lo amanhã. Ou então pode ser crime em determinada localidade e não ser em outra.

A idéia que é exposta quando do início do estudo do direito penal econômico, por exemplo, de que sua conceituação e noção dependem de uma valoração relativa e estrutural, ou seja, que dependerão e mudarão de acordo com determinado momento histórico e de consideração das leis vigentes em determinado Estado, pois é preciso a verificação dos valores e objetivos que o ordenamento estatal quer preservar; aplica-se, na realidade, em menor escala, em toda a consideração de ilícitos e sanções.

Essa idéia é mais aparente no direito penal econômico, pois a variação da intervenção estatal na economia é muito visível e oposta, indo historicamente desde o laissez-faire, laisse-passer, até uma economia totalmente dirigida pelo Estado. As relações Estado-atividade econômica têm as mais 
variadas matizes e graduações. ${ }^{4}$

Mesmo não se tratando de direito penal econômico, ter-se-á sempre que verificar qual a disciplina legislativa vigente em determinado país, e em uma certa época, para se conferir se há ilícito, e qual é o grau de ilicitude de determinada conduta.

Há sanções, assim, nos diversos campos do ordenamento jurídico. No direito civil, comercial, administrativo, trabalhista, penal etc., permeando o direito público e o direito privado.

Passando para um corte do tema e limitando o assunto àquilo que se pretende desenvolver, no direito administrativo-tributário utilizam-se duas designações para identificar se está-se diante de infrações e, por conseqüência, sanções penais, ou apenas infrações e penalidades na seara administrativa. No primeiro caso, tem-se o direito penal tributário. No segundo, cunhou-se a expressão "direito tributário penal", que é utilizada para designar o setor do direito tributário que comina sanções não criminais para determinadas condutas ilegais.

Nesse último caso visto acima, é que ter-se-iam as chamadas "infrações administrativas", ${ }^{5}$ que nada mais são que os ilícitos administrativos, os quais são penalizados com a aplicação de sanção administrativa, imposta e delimitada pela autoridade administrativa, mediante o procedimento administrativo. ${ }^{6}$ Isso porque são claramente identificáveis dois sistemas legais sancionatórios atuáveis pelo Estado: um, o criminal, implementado

\footnotetext{
4 A menção ao direito penal econômico não é meramente casual ou aleatória. O fato é que uma das grandes discussões atuais nesse ramo de estudo envolve a real necessidade de existência de um direito penal da economia ou, se não seria melhor adotar-se a solução de utilizar somente o Direito Administrativo Sancionador: "Em uma obra sobre Derecho penal econômico no podia faltar uma referencia a esta problemática dado ele enorme alcance que el poder sancionador de la Administración tiene frente a la infracción econômica. (...) es tradicional el estúdio de los limites ente el Derecho penal y el Derecho administrativo sancionador (también llamado Derecho penal administrativo), limites cuya descripción reviste sesgos de extrema necesidad cuando se trata Del Derecho penal econômico. Bastaría para ello com observar que los delitos econômicos em sentido estricto (delito fiscal, delitos contra la Seguridad social, fraude de subvenciones, delitos monetários, delitos de contrabando, blanqueo de capitales) em su versión atenuada constituyen infracciones administrativas, de modo que entre el delito y la contravención administrativa solo existe um limite cuantitativo em orden a la gravedad de la infracción. Pero, incluso aunque nos acercármos al derecho penal económico em sentido amplio, lãs fronteras com el Derecho administrativo sancionador siguen siendo muy próximas como ocurre com los delitos relativos a la defensa de la libre competência, los delitos contra el mercado y los consumidores o los delitos contra los trabajadores" (BAJO; BACIGALUPO. Derecho Penal Económico, p. 71-71).

5 Embora essa discussão se coloque no plano terminológico, tem raízes ontológicas, pois está ligada, em sua essência, à velha polêmica dos publicistas que investiga o discrimen entre as sanções administrativas e as penais. Em termos de antecedentes, entre as infrações administrativas - gênero do qual constituem espécies as infrações tributárias - e as penais (COSTA JR.; DENARI. Infrações tributárias e delitos fiscais, p. 8). 6 "como se vê, nesse aspecto, o direito tributário não cortou ainda o cordão umbilical com o direito administrativo (e talvez nem haja razões para fazê-lo). É que, em rigor, o que se opõe às infrações e às
} 
segundo o direito penal, mediante o instrumento do processo penal, no juízo criminal. O outro, inconfundível nos seus fundamentos e princípios regentes, o administrativo, aplicado segundo normas do direito administrativo, no procedimento administrativo, pelas autoridades administrativas.

Voltando à questão das diferenças e semelhanças entre as sanções administrativas (não-penais) e criminais.

Já foi dito que ambas as normas que prevêem as sanções são normas de conduta. Mas as dessemelhanças já são bem visíveis na origem das normas, ou seja, na competência legislativa para o estabelecimento das referidas sanções. As penalidades administrativas podem ser instituídas e delimitadas por quaisquer dos entes federais no âmbito de suas competências Constitucionais - União, Estados e Municípios. As sanções penais, por outro lado, somente têm origem por leis nacionais, de competência exclusiva da União, conforme o artigo 22 da Constituição da República.

No que pertine ao aspecto valorativo conferido ao bem jurídico tutelado pelo legislador, encontra-se outra diferenciação qualitativa. Apenas as condutas potencialmente comprometedoras da paz e da segurança jurídica e social é que podem e devem ser objeto de proteção por normas penais. É a aplicação prática do caráter fragmentário do Direito Penal na proteção dos bens jurídicos.

Lembre-se que o Direito Penal tem como princípio fundamental a intervenção mínima, segundo o qual a lei penal só deve intervir quando a proteção dos bens jurídicos tutelados não for eficaz de forma menos gravosa, constituindo a ultima ratio.

Como afirma Johannes Wessels: "as disposições penais, como 'ultima ratio', só se justificam onde meios menos incisivos (como os de Direito Civil ou do Direito Público) não bastem ao interesse de uma eficiente proteção aos bens jurídicos" (Direito penal: parte geral: aspectos fundamentais. Tradução de Juarez Tavares. Porto Alegre: Sergio Antonio Fabris, 1976. $\S 112$, p. 4).

Francisco de Assis Toledo, ao discorrer sobre a matéria, afirma que: "o direito penal, por sua natureza fragmentária, só vai até onde seja necessário para a proteção do bem jurídico. Não deve se ocupar de bagatelas”

sanções criminais são as infrações e as sanções administrativas, pois, enquanto aquelas são previstas no direito penal, aplicadas pelos juízes criminais, segundo o específico processo penal, estas outras são previstas em leis afetas à administração, aplicadas por autoridades administrativas, mediante procedimento administrativo" (AMARO. Direito tributário brasileiro, p. 411). 
(Princípios básicos de direito penal. 5. ed. São Paulo: Saraiva, 1999. p. 133).

A fragmentariedade surge como corolário do princípio da intervenção mínima, significando que o direito penal deve ser visto como fragmentário, ou seja, deve se ocupar de condutas mais graves, realmente lesivas à sociedade, sendo que as demais questões devem ser resolvidas pelos demais ramos do direito.

Assim, fracassando as outras formas de punição e de composição de conflitos, ou seja, não sendo resolvido pelo Direito Administrativo Sancionador, é que se lançará mão do direito penal, como ultima ratio. Daí a natureza subsidiária do direito penal: só será aplicado quando os demais ramos do direito se mostrarem insuficientes para proteger bens jurídicos relevantes.

Claus Roxin, citado por Nilo Batista, observa que: "a utilização do direito penal onde bastem outros procedimentos mais suaves para preservar e reinstaurar a ordem jurídica não dispõe da legitimação da necessidade social e perturba a paz jurídica, produzindo efeitos que afinal contrariam os objetivos do direito" (LOPES, Maurício Antônio Ribeiro. Princípio da insignificância no direito penal. 2. ed. São Paulo: Revista dos Tribunais, p. 68).

Também cabe ressaltar as dessemelhanças entre as sanções na consideração da natureza das penas aplicáveis. O Ordenamento jurídico brasileiro caracteriza-se por reservar aos autores de ilícitos criminais, de forma predominante, até como uma conseqüência da maior relevância da lesão ao bem jurídico tutelado, penas restritivas de liberdade, que podem vir ou não cumuladas com penas de natureza patrimonial.

Aos que cometem ilícitos administrativos há tão-somente a previsão de penas patrimoniais ou, no máximo, de sanções restritivas de direitos, como proibição de contratar com o Poder Público por um determinado lapso de tempo, ou então perda dos direitos políticos e até mesmo perda de cargos ou funções públicas.

Ainda considerando-se as notas que distinguem as sanções, é preciso ressaltar a questão do ente constitucionalmente responsável pela aplicação da penalidade. As sanções administrativas são passíveis de aplicação diretamente pela própria Administração, desde que observado o regular procedimento administrativo - assegurando-se o contraditório e a ampla defesa. As penas criminais somente podem ser aplicadas pela autoridade jurisdicional, no exercício inerente à sua razão de ser, mediante a utilização 
de um instrumento denominado de processo penal, regido pelo sistema acusatório e sob os princípios que se irradiam do devido processo legal, tais como o contraditório, ampla defesa, juiz natural, princípio da inocência, verdade real etc. ${ }^{7}$

Há que se referir a existência de outros critérios na doutrina para distinguir as sanções administrativas das sanções penais. Nesse sentido, pela peculiaridade dos critérios distintivos, e pela relevância da obra, enumero as diferenças entre penas administrativas e penais apresentadas por Ruy Cirne Lima:

a) enquanto as penas criminais são incomunicáveis, as administrativas, sob a forma de multa, podem ser reclamadas dos sucessores do infrator;

b) nos crimes a responsabilidade do réu deriva diretamente da prática do fato delituoso, enquanto nas infrações administrativas a responsabilidade é presumida, respondendo o infrator pelas fraudes praticadas por seu preposto;

c) o Direito Penal não admite a reformatio in pejus, mas ela pode ocorrer na esfera administrativa;

d) enquanto as penas criminais visam exclusivamente à punição, as administrativas cumulam punição e reparação do dano. (Princípios de direito administrativo. 6. ed. São Paulo: Revista dos Tribunais, 1982. p. 216)

\section{Ainda em relação à distinção de regência:}

Coube a Zanobini, posteriormente, em sua obra Sanções administrativas, trazer importante contribuição à matéria, procurando estabelecer uma distinção entre ilícitos penais, administrativos e civis. Enquanto os ilícitos penais traduzem turbação da ordem pública e social — substractum do Estado soberano —, os ilícitos administrativos implicam a violação dos deveres de colaboração com a Administração Pública; e os civis são aqueles próprios das relações de direito privado. Assim sendo, a diversidade das respectivas sanções decorreria da variedade dos respectivos preceitos, relacionados com a competência ou com o procedimento. (Le sanzioni amministrative, apud COSTA JR., Paulo José, DENARI, Zelmo. Infrações tributárias e delitos fiscais. 4. ed. São Paulo: Saraiva, 2000. p. 9)

\footnotetext{
7 Há juristas que encontram outras diferenciações entre as infrações penais e as administrativas: "Goldschmidt creyó encontrar la diferencia ontológica entre el injusto administrativo y el penal em que el Derecho penal protege derechos subjetivos o bienes jurídicos individualizados (según los cânones clásicos de derechos individuales independientes Del Estado), mientras que el Derecho administrativo debe operar frente a la desobediência de los mandatos emitidos por la Administración, que no protegen bienes jurídicos ya existentes, sino que están al servicio de los deberes de orden público y Del bienestar y que por ello no contienen um desvalor ético. Según esta concepción de debe reprender uma lesión contra la integridad corpora por médio de uma pena, mientras que el derecho de aparcar um vehículo incorrectamente debe ser reprendido solo por uma sanción administrativa, dado que es el mismo Estado el que há creado el objeto de la contravención, es decir, que no se trata de um interes espontaneamente surgido em la societad y, por tanto, tampoco de um dien jurídico" (BAJO; BACIGALUPO. Derecho Penal Económico, p. 77).
} 
Essas distinções fizeram com que a doutrina cunhasse uma distinção também terminológica na área do direito tributário para se referir às infrações e sanções administrativas, distinguindo-as dos delitos e penas criminais, facilitando o entendimento e identificação da matéria enfocada: Direito tributário penal e Direito penal tributário. Posto que essa seja a denominação mais comum, e seguindo na coerência do texto, é possível falar-se também em Direito tributário penal em distinção ao Direito administrativo penal, conferindo-se o mesmo entendimento da distinção terminológica primeira. ${ }^{8}$

A verdade é que tanto as normas penais quanto as normas administrativas não podem diferenciar-se em razão da natureza das violações por elas pressupostas. Em última, e primeira, análise, o Direito tributário penal nada mais é que o próprio Direito penal, assim como o Direito administrativo penal nada mais é que o Direito administrativo. Não há razão para se fragmentar a unidade sistêmica do Direito penal ou de Direito Administrativo em tantos ramos separados quantas são as violações normativas que se possam pressupor.

Toda vez que se estiver diante de uma norma dotada de sanção criminal, ela filia-se ao Direito Penal, e seu tratamento dogmático incumbe a esse ramo do Direito. E, da mesma forma, sempre que se estiver diante de uma imposição de sanção que não tenha a natureza criminal, não importa se a infração seja oriunda de norma tributária, ambiental, funcional, de trânsito e etc, estar-se-á no ramo do Direito Administrativo.

E é precisamente esse último o objeto do presente estudo, cabendo a adequada localização do tema neste capítulo, e a matização do tema tanto doutrinariamente quanto em relação à terminologia adequada, dando-se relevância ao ensinamento de Bobbio:

$\mathrm{Na}$ ciência do direito a correção terminológica é crucial, consoante já assinalou superiormente Ascarelli, que proclamou que a desgraça da Ciência Jurídica são as imprecisões terminológicas, chegando Norberto Bobbio a conceituar o Direito como análise da linguagem, conforme afirmado acima. Longe de ser

\footnotetext{
${ }^{8}$ Referimo-nos ao Direito Tributário Penal como o conjunto de normas jurídicas de caráter repressivo utilizadas especificamente na tutela das relações jurídicas tributárias, e ao Direito Administrativo Penal como o conjunto das normas jurídicas repressivas utilizadas pela Administração Pública para coibir condutas contrárias ao interesse público, envolvendo tanto as infrações urbanas (v.g., violações às normas de trânsito, de edificação, de saúde e segurança pública, de consumo) quanto às infrações ambientais (vg., violações às normas de preservação dos recursos naturais) (grifo meu) (COSTA JR.; DENARI. Infrações tributárias e delitos fiscais, p. 18).
} 
um modernismo, essa concepção remonta à Antiguidade, porquanto o filósofo Confúcio (551 1.C) já ressaltava a importância da linguagem para a condução das questões governamentais. (SILVA, Juary C. Elementos de direito penal tributário. São Paulo: Saraiva, 1998. p. 15-16)

\section{Novos paradigmas do Direito Administrativo}

Para estudar as transformações que o Direito Administrativo vem sofrendo nas últimas décadas e demonstrar a influência de algumas novas idéias nesse ramo do Direito, principalmente sobre o tema que se está desenvolvendo, é interessante fazer um paralelo entre os modelos históricos envolvidos. A comparação entre os elementos do Direito da Administração, passando do paradigma clássico para as idéias mais recentes e modernas tornará mais latentes e claras as transformações e seus efeitos sobre o tema objeto de análise na seqüência do texto - a punição na seara administrativa e seus efeitos e limites no Direito Administrativo Tributário.

Para essa comparação analítica, utilizar-se-á como embasamento e referência o excelente texto de Sabino Cassese "As Transformações do Direito Administrativo do Século XIX ao XXI”, o qual constrói um paralelo histórico do Direito Administrativo com base na contextualização das idéias expostas ao longo do seu trabalho, o que permite um melhor entendimento e explica aparentes contradições dos melhores doutrinadores europeus.

Logo no início, o autor italiano apresenta a primeira grande transformação do Direito Administrativo com base na teoria Francesa que se pode qualificar com base no conceito: "du service public". Leon Duguit, no seu livro escrito em 1913: As transformações do direito público, mostrou as profundas transformações no direito público no início do século XX, com a desaparição do sistema imperialista, vindo então a noção de serviço público substituir a noção de soberania, com mudança das noções de lei, de ato administrativo, de justiça administrativa e de responsabilidade do Estado.

Essas idéias foram esposadas um ano antes da eclosão da $1^{\mathrm{a}}$ guerra mundial e refletiam a latente oposição na época entre França e Alemanha. O autor Francês, um dos construtores do direito administrativo moderno na França, junto com Hauriou, enfatiza a passagem do direito administrativo da "pouissance publique", que se origina na Alemanha, para o "service public", noção francesa, embasada no ponto de vista antiautoritário e nacionalista. 
Para facilitar a compreensão das transformações do Direito Administrativo ao longo do século, segue-se também a forma utilizada pelo autor de referência, passando-se a apresentar de forma sucinta quais eram as características desse ramo do Direito no fim do século XIX, procurando-se, dentro do possível, historicizar as noções.

O século XIX foi marcado por algumas das grandes unificações na Europa, bastando lembrar as unificações Italiana e Alemã. Consolidaramse os Estados nacionais como uma reação aos Estados locais. Assim, o Direito Administrativo era nacional e centralizador, inclusive por ser um instrumento para viabilizar as unificações. Derrotados os defensores da autonomia local, os poderes foram dispostos segundo o critério da centralização.

Outro traço dominante do ramo do Direito em questão no final do século XIX era o princípio da supremacia da administração pública. O interesse público impunha ao interesse particular numerosos sacrifícios, havendo relações assimétricas e desiguais, com subordinação do particular à administração.

É nessa época que se entendia que tudo aquilo que diz respeito à administração somente é objeto de regulamento, e o legislador deveria se ocupar com os impostos e as leis em geral. Apenas para ilustrar, é contra esse entendimento que se desenvolve o princípio da legalidade. Mas ainda assim cunhou-se o termo discricionariedade como significado da possibilidade de escolha entre uma pluralidade de soluções igualmente permitidas pelo direito objetivo. Continuava o Direito Administrativo prevendo regimes exorbitantes, sendo unilateral.

A outorga de poderes exorbitantes à administração fazia com que esse ramo fosse considerado especial, diverso do direito privado, porque embasado nessa desigualdade, com reflexos sobre as noções de propriedade, contrato e responsabilidade, limitando-os.

É também característica marcante nesse período que a vontade circunstancial dos governos prevalecia sobre a vontade da administração pública. O Direito Administrativo, nas palavras de Cassese, era um direito eminentemente governativo.

Nessa época, a especialidade do Direito fez com que não se assimilasse a idéia de controle, principalmente jurisdicional. Havia uma separação entre matéria administrativa e matéria judiciária - entre administração e justiça.

Entende-se essa idéia inicial na evolução do Direito Administrativo, 
pois a Idade Média era a época das monarquias absolutas, tendo perdurado por muito tempo a noção de que o rei não podia ser submetido aos Tribunais, pois seus atos se colocavam acima de qualquer ordenamento jurídico. Nesse quadro de idéias é que se desenvolveu a teoria da irresponsabilidade do Estado.

Inclusive em período posterior, mas antes da Revolução Francesa, o Judiciário era tido como venal, que se negociava. O Legislativo é que despertava maior confiança e, nessa situação, não se podia permitir que o Judiciário controlasse os outros poderes. Lembre-se que o controle de constitucionalidade surgiu nos Estados Unidos, onde se confiava muito mais no Judiciário, ainda mais em comparação com os Parlamentos.

Mesmo após a Revolução Francesa, e conforme a idéia de Montesquieu, o Poder Judiciário seria neutro, em alguma dimensão nulo: "Dos três Poderes de que falamos, o de julgar é de certo modo nulo. Não restam senão dois" (O espírito das leis. 7. ed. São Paulo: Saraiva, 2000. p. 173). ${ }^{9}$

Cabe destacar que muitos autores entendem que somente se pode falar em Direito Administrativo como ramo autônomo, assim como os demais ramos do direito público, a partir do momento em que começou a desenvolver-se na fase do Estado Moderno, o conceito de Estado de Direito, estruturado sobre o princípio da legalidade e sobre o princípio da separação de poderes. Alguns vão a ponto de afirmar que o direito administrativo é produto exclusivo da situação gerada pela Revolução Francesa, só existindo nos países que adotaram os princípios por ela defendidos. ${ }^{10}$

Nesse sentido, o ensinamento do saudoso Hely Lopes Meirelles:

O impulso decisivo para a formação do Direito Administrativo foi dado pela teoria da separação dos Poderes desenvolvida por Montesquieu, L'Esprit des Lois, 1748, e acolhida universalmente pelos Estados de Direito. Até então, o absolutismo reinante e o enfeixamento de todos os poderes governamentais nas mãos do Soberano não permitiam o desenvolvimento de quaisquer teorias que

\footnotetext{
9 "O papel do Judiciário é modesto politicamente por duas razões. Primeira. Não se concebe o Judiciário posicionar-se no sentido de frear, embaraçar outro Poder. Todo posicionamento do Judiciário há de apresentar um conteúdo ético que lhe é essencial: há de ser justo, imparcial. E isso já limita sua capacidade de manobrar. Sabia-o Montesquieu, como ex-magistrado. Segunda. O Judiciário é o aplicador da lei por excelência. Seu trabalho consiste, em princípio, na aplicação das leis, leis elaboradas pelo Legislativo, com a participação do Executivo, mas inteiramente à revelia dele, Judiciário. Donde referir-se a ele Montesquieu como - 'a boca que pronuncia as palavras da lei'" (MONTESQUIEU, Charles de Secondat Baron de. O espírito das leis: as formas de governo, a federação, a divisão dos poderes, presidencialismo versus parlamentarismo, p. 27, nota de rodapé).

${ }^{10}$ DI PIETRO. Direito administrativo, p. 24.
}

A \& C R. de Dir. Administrativo e Constitucional, Belo Horizonte, ano 7, n. 27, p. 157-184, jan./mar. 2007 
visassem a reconhecer direitos aos súditos, em oposição às ordens do Príncipe.

Seguindo o autor de Regência, conforme inicialmente já referido, passa-se agora a examinar as transformações do Direito Administrativo ao longo do século XX, tendo por referência as características iniciais acima apontadas, e tendo por parâmetro final o encerramento do século, e início do século seguinte.

Desenvolve-se na Europa uma noção de condicionamento comunitário, de europeização. O Estado passa a não ser mais a única fonte do direito, havendo inclusive o reconhecimento de normas e princípios comunitários. Há uma crise de territorialidade do Estado e criam-se as administrações supranacionais.

Tudo isso gera uma internacionalização do Direito Administrativo, recebendo influência do direito comparado e há também a edição de norma comunitária sobre algumas matérias administrativas — inclusive com a gestação da União Européia.

Cabe a transcrição de trecho elucidativo de Cassese:

O vínculo entre direitos administrativos e os respectivos Estados não é desgastado somente (na área européia) pela europeização, mas, também, pela expansão da internacionalização dos Estados nacionais. Não há, hoje, setor do direito administrativo, desde a polícia para a tutela do meio ambiente até o controle das finanças e do comércio, no qual não existe uma organização internacional que estabeleça standards, fixe diretrizes, controles, etc.

Em conclusão, o direito administrativo, primeiramente ligado a qualquer Estado, apresenta-se, hoje, conectado a uma pluralidade de ordenamentos jurídicos. ${ }^{11}$

Evolui-se, também, para uma consideração de interesse público acima tanto do interesse da administração como do interesse particular. Há uma busca pelo regime de negociação e igualdade entre administração e administrados. A superação da unilateralidade retira o cidadão da posição de subordinação e surge uma noção de administração consensual, até pela crescente colaboração e parceria entre o privado e a Administração.

O Direito Administrativo se aperfeiçoa por meio de formas privatísticas, havendo uma expansão dos serviços públicos com gestão privada, com vistas à agilização da ação administrativa.

${ }^{11}$ CASSESE, Sabino. As transformações do direito administrativo do século XIX ao XXI. Revista Interesse Público, Porto Alegre: Notadez, n. 24, mar./abr. 2004, p. 13-23. 
Também vislumbra-se outra característica da evolução do instituto em análise, a minimização das influências dos governos e das ideologias sobre a Administração Pública, cujo exemplo mais atual e marcante são as agências regulatórias. A gênese foi a influência da Comissão da União Européia para a separação entre política e administração. Há criação de modelos multiorganizativos, que não dependem mais de um único centro.

Molda-se nesse contexto um Direito comprometido com a idéia de controle jurisdicional, deixando-se para trás a noção de que a Administração Pública era subordinada ao Poder Legislativo, mas independente do Judiciário. Com a mudança de paradigmas, quanto mais liberdade há na realização da manifestação de vontade da Administração, mais necessidade de fundamentação, para permitir a efetiva realização do controle.

O juízo administrativo adquire todo o arsenal de poderes jurisdicionais nas questões administrativas, enquanto antes, conforme esclarece Cassese, em respeito à regra pela qual a Administração Pública era subordinada ao Poder Legislativo, mas independente do Judiciário, o juiz tinha poderes limitados nos conflitos.

No trabalho científico de referência, o autor Italiano conclui apresentando as características e paradoxos que essas transformações acarretam no Direito Administrativo. Destaca-se aqui a questão das numerosas contradições em decorrência, principalmente, da rapidez das seqüentes transformações. Disso gerou que o novo Direito Administrativo convive com o velho Direito Administrativo, até porque as transformações ocorrem por área, não sendo gerais, além do que a mentalidade do intérprete não avança de forma uníssona e harmônica.

É com base nesse contexto de idéias atual, tendo por pano de fundo as transformações que o Direito Administrativo vem sofrendo ao longo das últimas décadas, que se pretende prosseguir no capítulo seguinte com a apresentação dos limites ao poder do Estado de impor multas administrativas.

Destacando-se, a partir do capítulo seguinte, a ampla possibilidade de controle jurisdicional nos novos parâmetros, dando-se enfoque à superação da idéia de que o legislador era juridicamente ilimitado, e que passa o Soberano a não encontrar mais apenas na lei natural a sua limitação. Construção essa que ganhou contornos com o desenvolvimento no âmbito do Direito Administrativo Alemão do princípio da proporcionalidade.

Sempre se tendo bem em conta que, embora não seja exigível e 
possível ao intérprete a mudança total dos paradigmas, até porque não é isso que a evolução da ciência jurídica precisa, mas sim uma consideração crítica e conjunta dos vetores todos que moldaram o Direito Administrativo ao longo de sua evolução histórica, é necessário passar a se enfrentar os problemas com a devida relevância aos novos paradigmas.

\section{A incidência dos princípios do não-confisco e da proporciona- lidade sobre as multas tributárias pecuniárias}

Já foram apresentados nos capítulos anteriores as noções de sanções administrativas e a sua identificação no ordenamento jurídico, definindo que elas decorrem de uma infração administrativa, seja em que área for, ambiental, tributária etc, distinguindo-se, portanto, das sanções criminais. Foi também feita uma narrativa crítica da evolução do Direito Administrativo ao longo do último século, chegando-se até o atual estágio dos novos paradigmas e dos valores e idéias que passaram a fazer parte desse ramo do Direito e que devem estar presentes quando do estudo de quaisquer dos institutos do Direito Administrativo.

Passa-se neste capítulo, então, a discorrer e sustentar a corrente de idéias que propugna por uma maior limitação do poder do Estado de instituir sanções pecuniárias sobre as infrações administrativo-tributárias com base nos Princípios do não-confisco e da proporcionalidade, salientando-se que a ordem pública não confere liberdade ao administrador para agir em dissonância com tais os elevados princípios jurídico-administrativos, e que "quem administra é o próprio Direito Público, não o agente na sua particularidade, nem mesmo a Administração Pública, considerada, por igual, na sua particularidade". ${ }^{12}$

\section{4.a Princípio do não-confisco}

Para o desenvolvimento dessa análise, ter-se-á em conta a decisão do egrégio Supremo Tribunal Federal nos autos da ação direta de inconstitucionalidade $\mathrm{n}^{\mathrm{o}}$ 551-1 que suspendeu liminarmente a vigência dos parágrafos $2^{\circ}$ e $3^{\circ}$ do artigo 57 do Ato das Disposições Constitucionais Transitórias da Constituição do Rio de Janeiro, que tinham o seguinte conteúdo:

Art. $57-(\ldots)$

12 FREITAS. Estudos de direito administrativo, p. 14. 
$\S 2^{\circ}$ - As multas conseqüentes do não recolhimento dos impostos e taxas estaduais aos cofres do Estado não poderão ser inferiores a duas vezes o seu valor.

$\S 3^{\circ}$ - As multas conseqüentes da sonegação dos impostos ou taxas estaduais não poderão ser inferiores a cinco vezes o seu valor.

Vê-se que os referidos dispositivos pretenderam, primeiro, estabelecer pena pecuniária mínima de $200 \%$ sobre o valor do tributo em caso de não recolhimento de impostos e taxas; segundo, fixar como patamar mínimo para as multas decorrentes de sonegação o montante de $500 \%$ o valor do tributo.

A norma Constitucional que estabelece o princípio da vedação de confisco está localizada na matéria que trata das limitações Constitucionais ao poder de tributar, no inciso IV do artigo 150. Por se tratar de um conceito jurídico indeterminado, será preciso uma valoração do que pode se entender como confisco. O fato é que a dificuldade do trabalho residirá sempre na zona de incerteza, cinzenta, na qual não há como se fazer um juízo categórico, afirmando-se peremptoriamente pela existência ou não do confisco.

Com isso, deixa-se transparecer que, mesmo sendo feito um exercício de interpretação, não será possível uma delimitação aprioristicamente, em tese, do que seja confisco. Permitir-se-á apenas estabelecer alguns parâmetros e balizamentos, mas sem uma definição que vá ter resultados definitivos em todos os casos..$^{13}$

Pode-se incluir no princípio do não-confisco três valores que certamente orientaram a sua gênese na idéia dos juristas. A propriedade privada em primeira análise, que não poderia ser atingida, a não ser nos casos expressos, definidos na legislação e em conformidade com a Constituição. Certo que a instituição de um tributo que, na prática, tenha o resultado de retirar propriedade do contribuinte, deixará de ser exação tributária para se configurar em confisco pela privação do patrimônio e renda. A imposição confiscatória equivale à expropriação da riqueza sobre a qual incida.

Também a observância da capacidade contributiva, pela injusta

\footnotetext{
${ }^{13}$ De forma similar aos demais conceitos indeterminados a que nos referimos alhures, a aferição da ocorrência do funesto confisco deve ser observada no caso concreto, e não sob o invólucro de conjecturas frias e com elevado grau de abstração que deve imperar quando do manejo da atividade normativa. (...) Apesar de todo o esforço que se desprenda com vistas à formulação mais concreta do que possa corresponder quantitativamente o não-confisco em termos de adequação da lei tributária à razoabilidade, pensamos que somente se poderá saber se o importe tributário é ou não razoável analisando-se cada caso concreto e levando-se em conta as condições de tempo e lugar e os fins econômicos e sociais de cada imposto" (FREITAS, L. Da estendabilidade do princípio do não-confisco às multas tributárias pecuniárias. Revista Tributária e das Finanças Públicas, p. 216).
} 
transferência patrimonial do contribuinte ao fisco - injusta pela sua monta e porque aniquila o ativo patrimonial ${ }^{14}$ - e a consideração ao princípio da proporcionalidade (razoabilidade), certamente influenciaram na construção do princípio que veda o confisco. Nesse sentido: "O princípio que veda o confisco nada mais é do que a síntese silogística de outros três princípios indeléveis de nossa ordo iuris, quais sejam, (i) a proteção da propriedade privada, (ii) o princípio da capacidade contributiva e (iii) o princípio da razoabilidade (condensado com o da proporcionalidade)" ${ }^{15}$

Afora essas questões quanto à conceituação e conteúdo do princípio que veda o confisco, o mais relevante nessa análise será aferir a extensão desse princípio, ou seja, se ele se aplica também em matéria de sanção administrativa pecuniária.

Nesse momento nota-se a relevância da consideração primeira feita acerca do embasamento axiológico do princípio do não-confisco, quando da busca de sua delimitação. Isso porque, quando se conclui, sem maiores contradições ou incoerências, que no cerne da vedação de confisco estão a preservação da propriedade privada - privação da propriedade somente por desapropriação - e da razoabilidade, certo deve ser também a conclusão de que esses valores do ordenamento jurídico devem ser levados em questão quando da delimitação do limite às sanções pecuniárias.

Assim, e por um raciocínio simples de lógica, mas de coerência, a vedação do confisco é valor que permeia toda a ordem jurídica, devendo, inclusive, reger o legislador quando da delimitação das penas pecuniárias na seara administrativo-tributária.

Nesse sentido, Sacha Calmon Navarro Coêlho afirmou que o confisco é genericamente vedado na nossa ordem jurídica, sendo admitido tão-somente nos casos expressamente elencados pelo constituinte e pelo legislador complementar, quais sejam: a) danos causados ao erário, b) enriquecimento ilícito no exercício de cargo, função ou emprego na Administração Pública e c) utilização de terra para cultivo de ervas alucinógenas. Na mesma análise, segue o autor aduzindo que: "uma multa excessiva ultrapassando o razoável para dissuadir ações ilícitas e para punir os transgressores (...) caracteriza, de fato, uma maneira indi-

\footnotetext{
14 BIELSA. Estúdios de Derecho Público, p. 83.

${ }^{15}$ FREITAS, L. Da estendabilidade do princípio do não-confisco às multas tributárias pecuniárias. Revista Tributária e das Finanças Públicas, p. 214.
} 
reta de burlar o dispositivo constitucional que proíbe o confisco. Este só poderá se efetivar se e quando atuante sua hipótese de incidência e exige um processus. A aplicação de uma medida de confisco é algo totalmente diferente da aplicação de uma multa. Quando esta é tal que agride violentamente o patrimônio do cidadão contribuinte, caracteriza-se como confisco indireto e, por isso, é inconstitucional". ${ }^{16}$

Acresça-se ainda a essa linha de argumentação lógica, um argumento mais de ordem hermenêutica, uma vez que um dos direitos fundamentais do indivíduo é que ninguém será privado de sua liberdade ou de seus bens sem o devido processo legal. Assim, tratando-se de penalidade administrativa (não penal destaque-se), não há como se admitir uma pena que atinja o próprio direito de propriedade do particular, em face da excessiva quantificação de seu valor, sem que isso ocorra no bojo de um processo jurisdicional, e não em simples contraditório mitigado do procedimento administrativo.

Voltando agora ao acórdão de referência nesse estudo, a decisão do egrégio Supremo Tribunal Federal na ação direta de inconstitucionalidade $\mathrm{n}^{\mathrm{o}}$ 551-1, lê-se do voto do relator o Ministro Ilmar Galvão o seguinte trecho, e que vem ao encontro do que está sendo afirmado acima:

O art. 150, IV, da Carta da República veda a utilização de tributo com efeito confiscatório. Ou seja, a atividade fiscal do Estado não pode ser onerosa a ponto de afetar a propriedade do contribuinte, confiscando a título de tributação. Tal limitação ao poder de tributar estende-se, também, às multas decorrentes de obrigações tributárias, ainda que não tenham elas natureza de tributo. Nesse sentido, o RE 91.707, Rel. Mm.Moreira Alves, cujo acórdão foi assim ementado: - ICM. Redução de multa de feição confiscatória. - Tem o S.T.F. admitido a redução de multa moratória imposta com base em lei, quando assume ela, pelo seu montante desproporcionado, feição confiscatória.

Na seqüência do seu voto, o Ministro relator concluiu que: "Desse modo, o valor mínimo de duas vezes o valor do tributo como conseqüência do não-recolhimento apresenta-se desproporcional, atentando contra o patrimônio do contribuinte, em evidente efeito de confisco.Igual desproporção constata-se na hipótese de sonegação, na qual a multa não pode ser inferior a cinco vezes o valor da taxa ou imposto, afetando ainda mais o patrimônio do contribuinte".

${ }^{16}$ COÊLHO. Teoria e prática das multas tributárias, p. 65, 67.

A \& C R. de Dir. Administrativo e Constitucional, Belo Horizonte, ano 7, n. 27, p. 157-184, jan./mar. 2007 
O Ministro Sepúlveda Pertence acompanhou o voto do relator e afirmou que: "Também não sei a que altura um tributo ou uma multa confiscatório; mas uma multa de duas vezes o valor do tributo, por mero retardamento de sua satisfação, ou de cinco vezes, em caso de sonegação, certamente sei que é confiscatório e desproporcional". ${ }^{17}$

Conclui-se, portanto, que não há como se sustentar a não incidência da vedação do confisco em sede de penalidades administrativo-tributárias e, acrescenta-se, em qualquer penalidade pecuniária decorrente de infração à norma administrativa será indispensável a aferição de sua legitimidade com base no princípio constitucional do não-confisco.

Isso porque, conforme já afirmado, trata-se de princípio que permeia todo o ordenamento jurídico, em razão de sua fundamentação e axiologia pretendida, não havendo sentido em restringi-lo apenas às exações tributárias.

\section{4.b Princípio da proporcionalidade}

Foi importante a noção sintética conferida em capítulo anterior sobre a evolução e transformações do Direito Administrativo, para se acrescentar agora a questão do princípio da proporcionalidade.

Ao contrário do que muitos pensam, esse princípio originou-se no Direito Administrativo Alemão, e não no Direito Constitucional. Desenvolveu-se, originariamente, no âmbito do direito administrativo, mas especificamente, das normas sobre o poder de polícia e seus limites.

É verdade que o reconhecimento doutrinário e jurisprudencial que outorgou ao princípio a vinculação do próprio legislador, alçando-o, portanto em importância e aplicação, pois agora sim teria ampla utilização, apenas com a vigência da Lei Fundamental da Alemanha após 1949. ${ }^{18}$

Viu-se acima a transposição do Direito Administrativo do Soberano, para o Direito Administrativo do interesse público, regulado pelo princípio da legalidade. Pois agora já se está diante de uma nova transposição, da reserva legal à reserva da lei proporcional.

O princípio da proporcionalidade, tal como hoje é compreendido,

\footnotetext{
${ }^{17}$ Do estrato de ata do julgamento se extrai que: "Decisão: O Tribunal, por unanimidade, julgou procedente o pedido formulado na inicial da ação direta para declarar a inconstitucionalidade dos $\S 2^{\circ}$ e $3^{\circ}$ do artigo 57 do Ato das Disposições Constitucionais Transitórias da Constituição do Estado do Rio de Janeiro. Votou o Presidente, o Senhor Ministro Marco Aurélio, Ausentes, justificadamente, o Senhor Ministro Celso de Mello, e, neste julgamento, o Senhor Ministro Nelson Jobim e a Senhora Ministra Ellen Gracie, Plenário, 24.10.2002".
} 
somente se fez possível a partir de três pilares consolidados no século XIX, a saber: a) a supremacia da constituição, que insere o pressuposto de que o sistema jurídico está organizado de forma escalonada, devendo as leis ordinárias guardar, necessariamente, respeito à ordem constitucional; b) a possibilidade de controle da constitucionalidade das leis, pois de nada adiantaria a supremacia da constituição, se não fosse dado a um órgão do Estado o poder de verificar a compatibilidade da legislação ordinária ao texto constitucional, no exercício do controle da constitucionalidade; c) a existência de um rol de direitos consagrados como fundamentais, o que atua como um limitador ao poder do legislador ordinário de conformação da ordem jurídica, passando-se da noção de Estado de Direito para a idéia de Estado Constitucional de Direito.

Com a Constituição da República Federal da Alemanha de 1949, tanto a administração quanto o legislador e os órgãos judiciários, passaram a ser objeto de vinculação à Constituição e, de modo especial, aos direitos fundamentais nela consagrados. Houve aí, portanto, uma radical alteração do pensamento jurídico-constitucional de controle da atividade legisladora, pois esse passou a ter também sua atuação aferida pelo parâmetro Constitucional, não apenas quanto à forma, mas também quanto ao conteúdo das leis.

Nesse sentido, preciso o ensinamento de Heinrich Scholler:

denominaram essa transformação como significando uma evolução do princípio da "reserva de lei" para o princípio da "reserva de lei proporcional". (...) De regra, contudo, o princípio da reserva de lei significa apenas a indispensabilidade de uma lei no sentido material, isto é, que basta a existência de um decreto ou regulamento como fundamento para um ato administrativo. Percebe-se, desde logo, que a reserva da lei proporcional poderá significar tanto uma reserva da lei proporcional no sentido formal quanto no sentido material. ${ }^{19}$

O Tribunal Federal Constitucional (República da Alemanha), a partir na idéia de uma relação entre os fins e os meios, sempre acentuou que a natureza da vinculação do legislador justamente se caracteriza pelo

\footnotetext{
18 "Esta linha evolutiva, do direito administrativo para o Constitucional, encontra explicação na circunstância de que, inicialmente, com base na idéia da soberania popular, o legislador era ido como juridicamente ilimitado. Esta concepção tinha validade geral e encontrou sua expressão mais significativa no princípio britânico de acordo com o qual o Parlamento pode fazer tudo, menos transformar um homem numa mulher e uma mulher num homem. (...) Isto significava que apenas a lei natural poderia limitar o soberano, isto é, o legislador democraticamente eleito" (SCHOLLER. O princípio da proporcionalidade no direito constitucional e administrativo da Alemanha. Revista da Ajuris, p. 269).
} 
fato de que ele se encontra sujeito ao controle do Tribunal no que diz com a observância do princípio da proporcionalidade. No momento em que se reconhecer o princípio da reserva legal como sendo o da reserva da lei proporcional, passou a ser admitida a possibilidade de impugnação e eliminação não apenas das medidas administrativas desproporcionais, mas também das leis que, ofensivas à relação entre os meios e os fins, estabelecem restrições aos direitos fundamentais. ${ }^{20}$

Pela adequação, aponta-se para a necessidade de a medida restritiva ser apropriada para a prossecução dos fins invocados pela lei (conformidade com os fins). A restrição ao direito fundamental deve ser apta a produzir o fim colimado.

A exigência da necessidade pretende evitar a adoção de medidas restritivas de direitos que não sejam necessárias para se obterem os fins de proteção visados pela Constituição, ou seja, existindo várias medidas possíveis para se alcançar a finalidade pretendida, deve ser eleita aquela menos gravosa aos interesses do cidadão. A violação da vida privada não pode ser simplesmente um meio para obviar a dificuldade da administração de chegar a uma determinada informação. A limitação não será necessária quando um meio mais ameno seria suficiente para atingir idêntica finalidade.

O princípio da proporcionalidade em sentido estrito significa que uma lei restritiva, mesmo adequada e necessária, pode ser inconstitucional, quando adote cargas coativas de direitos desmedidas, desajustadas, desproporcionadas em relação aos resultados obtidos, bem como servirá para indicar, entre as possibilidades jurídicas, se o meio utilizado se encontra em proporção com o fim perseguido. É o momento da ponderação dos bens em jogo. ${ }^{21}$

Bonavides defende que o princípio da proporcionalidade está inserido no ordenamento jurídico constitucional brasileiro:

Poder-se-á enfim dizer, a esta altura, que o princípio da proporcionalidade é hoje axioma do Direito Constitucional, corolário da constitucionalidade e cânone do Estado de direito, bem como regra que tolhe a ação ilimitada do poder do Estado no quadro de juridicidade de cada sistema legítimo de autoridade. A ele não poderia ficar estranho, pois, o Direito Constitucional brasi-

\footnotetext{
19 SCHOLLER. O princípio da proporcionalidade no direito constitucional e administrativo da Alemanha. Revista da Ajuris, p. 271-271.

${ }^{20}$ SCHOLLER. O princípio da proporcionalidade no direito constitucional e administrativo da Alemanha. Revista da Ajuris, p. 272-273.
} 
leiro. Sendo, como é, princípio que embarga o alargamento dos limites do Estado ao legislar sobre matéria que abrange direta ou indiretamente o exercício da liberdade e dos direitos fundamentais, mister se faz proclamar a força cogente de sua normatividade. ${ }^{22}$

Além de ser um princípio de hierarquia Constitucional, é preciso reconhecer que no âmbito do Direito Administrativo o princípio obteve previsão legal expressa no inciso VI, do parágrafo único do artigo $2^{\circ}$ a lei que regula o processo administrativo no âmbito da Administração Pública, Lei n ${ }^{\circ} 9.784$ de 29 de janeiro de 1999.

De tudo isso, é inafastável a conclusão de que o Princípio da Proporcionalidade se aplica na interpretação das leis conforme a Constituição, e igualmente esfera dos atos discricionários, na interpretação de conceitos jurídicos (indeterminados), assim como no caso da avaliação da necessidade de uma determinada medida coercitiva ${ }^{23}$ e ainda na aferição da extensão e limites dessas imposições, para que haja adequação entre os meios e os fins.

Nesse sentido, ilustrando a conclusão a que ora se chegou:

A função bloqueadora do princípio da proporcionalidade exige que a constitucionalidade das sanções concretamente impostas sejam avaliadas, sobretudo, diante do nível de limitação que elas impõem à esfera jurídica do indivíduo infrator (...) Esta é uma imposição que vincula em primeiro lugar o legislador e, em segundo plano, a autoridade administrativa, a quem compete concretamente atingir a finalidade objetivada pelo comando legal sancionatório sem negligenciar o atendimento às condições individuais do infrator. A autoridade administrativa deve (...) procurar buscar a máxima concretização do objetivo legal sancionatório, impondo a menor restrição possível à esfera jurídica do indivíduo infrator, tarefa que, por óbvio, não é de fácil execução, mas que deve nortear a atividade daquela autoridade. (PONTES, Helenilson Cunha. O princípio da proporcionalidade e o direito tributário. São Paulo: Dialética, 2000. p. 138)

Com base nesse entendimento é que entendo inaplicável, em casos concretos os quais vêm a julgamento, a incidência de percentual de multa moratória excessivo, e além dos patamares de razoabilidade, conforme trecho de sentença por mim prolatada no processo $\mathrm{n}^{\mathrm{o}} 2003$.

\footnotetext{
${ }^{21}$ CANOTILHO, José Joaquim Gomes. Direito constitucional e teoria da constituição. 4. ed. Coimbra: Almedina, p. 447.

22 Curso de direito constitucional. 10. ed. São Paulo: Malheiros, 2000. p. 397

${ }^{23}$ SCHOLLER. O princípio da proporcionalidade no direito constitucional e administrativo da Alemanha. Revista da Ajuris, p. 281.
} 


\subsubsection{8-5, da Vara federal de Bento Gonçalves:}

Em relação aos percentuais de multa moratória aplicada, impõe-se maior aprofundamento.

Há uma margem de discricionariedade na fixação dos percentuais de sanção pecuniária, tanto ao legislador como ao fisco quando da aplicação efetiva da multa. Entretanto, como a embargante questionou o elevado percentual das multas que lhe foram aplicadas, entendo que, “...pode o Poder Judiciário, atendendo às circunstâncias do caso concreto, reduzir multa excessiva aplicada pelo Fisco". (Decisão do Supremo Tribunal Federal, no RE $n^{\circ}$ 82.510/SP. Rel. Ministro Leitão de Abreu. RTJ 78/610-611)

Muitas vezes se esquece que a simples edição de uma legislação não a torna aplicável. É preciso compatibilizá-la com a Constituição da República. E esta prevê uma série de limitações ao poder de tributar dos entes estatais, dentre os quais aquele previsto no art. 150, inciso III, da Constituição Federal, que estabelece:

Art. 150. Sem prejuízo de outras garantias asseguradas ao contribuinte, é vedado à União, aos Estados, ao Distrito Federal e aos Municípios: IV - utilizar tributo com efeito de confisco.

Desse modo, posto que haja dificuldade na delimitação do que deve se ter por confisco, o certo é que não haveria dúvida de que a utilização de uma alíquota que correspondesse a $100 \%$ da base de cálculo seria uma tributação abusiva, em razão deste dispositivo mencionado. Também não tenho dúvida que a utilização de multa moratória no percentual $100 \%$ do valor do tributo principal também atinge este dispositivo Constitucional. E, mais grave, atinge o princípio da proporcionalidade.

No que concerne ao princípio da proporcionalidade, é sempre válida a lição do constitucionalista Gilmar Ferreira Mendes:

Não estava claro, até muito recentemente, se o Tribunal "o STF" — in casu — entendia configurar o princípio da proporcionalidade postulado imanente aos direitos fundamentais,se os extraía do próprio princípio da reserva legal ou do princípio do Estado de Direito. Na decisão de 11 de março de 1994, enfatizou, porém, o Ministro Moreira Alves que o princípio da proporcionalidade ou da razoabilidade tinha assento constitucional na cláusula do devido processo legal, entendida enquanto garantia material”. Essa decisão está contida na ADIn 958, Relator: Ministro Marco Aurélio, publicada no DJ I, p. 11675, 16 maio 1994. (Jurisdição constitucional. São Paulo: Saraiva, 1996. p. 177-178)

É irrazoável e desproporcional que ante o descumprimento de uma

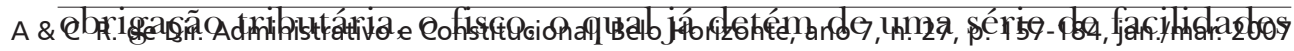


na realização de seus créditos tributários, imponha ainda uma sanção monetária correspondente a $100 \%$ do valor dos tributos devidos. E não é muito recordar que sobre estes valores já incidirá a correção monetária e os juros de mora - cuja origem não se confunde com a multa moratória, além do chamado encargo legal pelo simples exercício da cobrança em juízo.

Não estará o julgador legislando quando afasta a vigência de normas desse jaez, o que faz dentro do controle judicial, que não pode admitir que uma multa seja fixada em valor excessivo, a ponto de inviabilizar a vida financeira da empresa punida. Sendo, pois, de natureza confiscatória, não podia e não pode a norma que fixa a multa de mora imposta no patamar de $100 \%$ ser aplicada validamente pelo Poder Judiciário.

\section{Conclusão}

Há uma diferenciação qualitativa entre as infrações e sanções penais e as infrações e sanções administrativas. Posto que a estrutura da norma jurídica abstratamente prevista seja muito parecida, ou até mesmo idêntica, um enfoque analítico concluirá pela existência de algumas dissensões na razão de ser e fundamentos teóricos e práticos na incidência dessas penalidades.

Na seara administrativa, reconhece-se a existência de uma limitação quanto à natureza e quantificação das penalidades aplicáveis, as quais devem estar expressamente previstas em lei — princípio da legalidade. No entanto, no que pertine à delimitação da extensão da multa pecuniária, dentro dos parâmetros legais haverá exercício do poder discricionário da Administração na definição da quantificação da penalidade, tratando-se de mérito do ato administrativo.

Até pouco tempo, a doutrina quase que majoritária sustentava que não poderia haver controle jurisdicional sobre esse mérito do ato administrativo. Pelo escólio de Hely Lopes Meirelles, os motivos e objeto da manifestação de vontade administrativa não poderiam ser aferidos pelo judiciário em relação aos seus critérios de conveniência e oportunidade.

Colocava-se, assim, a matéria do Direito Administrativo sancionatório sob a guarida dessa corrente de idéias, sustentando-se que o Judiciário não poderia aferir a legalidade da imposição de uma penalidade pecuniária pela Administração houvesse lastro na legislação.

No entanto, com as transformações de paradigmas do Direito Admi-

A \& C R. de Dir. Administrativo e Constitucional, Belo Horizonte, ano 7, n. 27, p. 157-184, jan./mar. 2007 
nistrativo, está-se alcançando uma fase de evolução doutrinária em que não há mais como se sustentar a inexistência desse controle. Retirou-se o anteparo doutrinário dos atos administrativos discricionários. Esses, até mais do que os atos vinculados, devem estar devidamente fundamentados. E será com base na verificação dessa fundamentação, e da sua conformação com os princípios Constitucionais da Proporcionalidade, da vedação de confisco e da razoabilidade que se poderá expungir do ordenamento jurídico punições moratórias que atentam contra o sentimento médio de justiça - utilizando-se a letra da lei, para evitar o subjetivismo - "vedandose a imposição de obrigações, restrições e sanções em medida superior àquelas estritamente necessárias ao atendimento do interesse público". ${ }^{24}$

Florianópolis, 30 de junho de 2005.

\section{Referências}

AMARO, Luciano. Direito tributário brasileiro. 2. ed. São Paulo: Saraiva, 1998.

BAJO, Miguel; BACIGALUPO, SIlvina. Derecho Penal Económico. Madrid: Centro de Estúdios Ramón Areces. Colección Ceura.

BECKER, Alfredo Augusto. Teoria geral do direito tributário. 3. ed. São Paulo: Lejus, 1998

BIELSA, Rafael. Estúdios de Derecho Público. Buenos Aires: Depalma, 1951. v. 2.

CASSESE, Sabino. As transformações do direito administrativo do século XIX ao XXI. Revista Interesse Público, São Paulo, n. 24, mar./abr. 2004.

CIRNE LIMA, Ruy. Princípios de direito administrativo. 6. ed. São Paulo: Revista dos Tribunais, 1982.

COÊLHO, Sacha Calmon Navarro. Teoria e prática das multas tributárias. 2. ed. Rio de Janeiro: Forense, 2001.

COSTA JR., Paulo José; DENARI, Zelmo. Infrações tributárias e delitos fiscais. 4. ed. São Paulo: Saraiva, 2000

DI PIETRO, Maria Sylvia Zanella. Direito administrativo. 11. ed. São Paulo: Atlas, 1999.

FREITAS, Juarez. Estudos de direito administrativo. 2. ed. rev. e atual. São Paulo: Malheiros, 1997.

FREITAS, Leonardo e Silva de Almeida. Da estendabilidade do princípio do não-confisco às multas tributárias pecuniárias. Revista Tributária e das Finanças Públicas, São Paulo, ano 12, n. 54.

FURLAN, Anderson. Sanções penais tributárias. In: MACHADO, Hugo de Brito (Coord.). Sanções penais tributárias. São Paulo; Fortaleza: Dialética/ICET, 2005. p. 11-99.

MARTINS, Ives Gandra da Silva. Da sanção tributária. 2. ed. São Paulo: Saraiva, 1998.

${ }^{24}$ Inc. VI, parágrafo único, art. $2^{\circ}$ da Lei nº 9.784/99. 
MEIRELLES, Hely Lopes. Direito administrativo brasileiro. 25. ed. Atualizada por Eurico de Andrade Azevedo, Délcio Balestero Aleixo e José Emmanuel Burle Filho. São Paulo: Malheiros, 2000.

MELlo, Celso Antônio Bandeira de. Curso de direito administrativo. 10. ed. São Paulo: Malheiros, 1998.

MONTESQUIEU, Charles de Secondat Baron de. O espirito das leis: as formas de governo, a federação, a divisão dos poderes, presidencialismo versus parlamentarismo. Introdução, tradução e notas Pedro Vieira Mota. 7. ed. São Paulo: Saraiva, 2000.

PEREIRA, Frederico Valdez. Uma leitura constitucional da proteção ao sigilo bancário. Revista dos Tribunais, São Paulo, v. 804, p. 115-130, out. 2002.

PONTES, Helenilson Cunha. O princípio da proporcionalidade e o direito tributário. São Paulo: Dialética, 2000.

SCHOLLER, Heinrich. O princípio da proporcionalidade no direito constitucional e administrativo da Alemanha. Revista da Ajuris, Rio Grande do Sul, v. 1, n. 75, 1999.

SILVA, Juary C. Elementos de direito penal tributário. São Paulo: Saraiva, 1998.

ZAVASCKI, Teori Albino. Antecipação da tutela. 2. ed. São Paulo: Saraiva, 1999.

Informação bibliográfica deste texto, conforme a NBR 6023:2002 da Associação Brasileira de Normas Técnicas (ABNT):

PEREIRA, Frederico Valdez. Limites à imposição de sanções administrativas: multas pecuniárias tributária. A\&C Revista de Direito Administrativo e Constitucional, Belo Horizonte, ano 7, n. 27, p. 157-184, jan./mar. 2007. 